
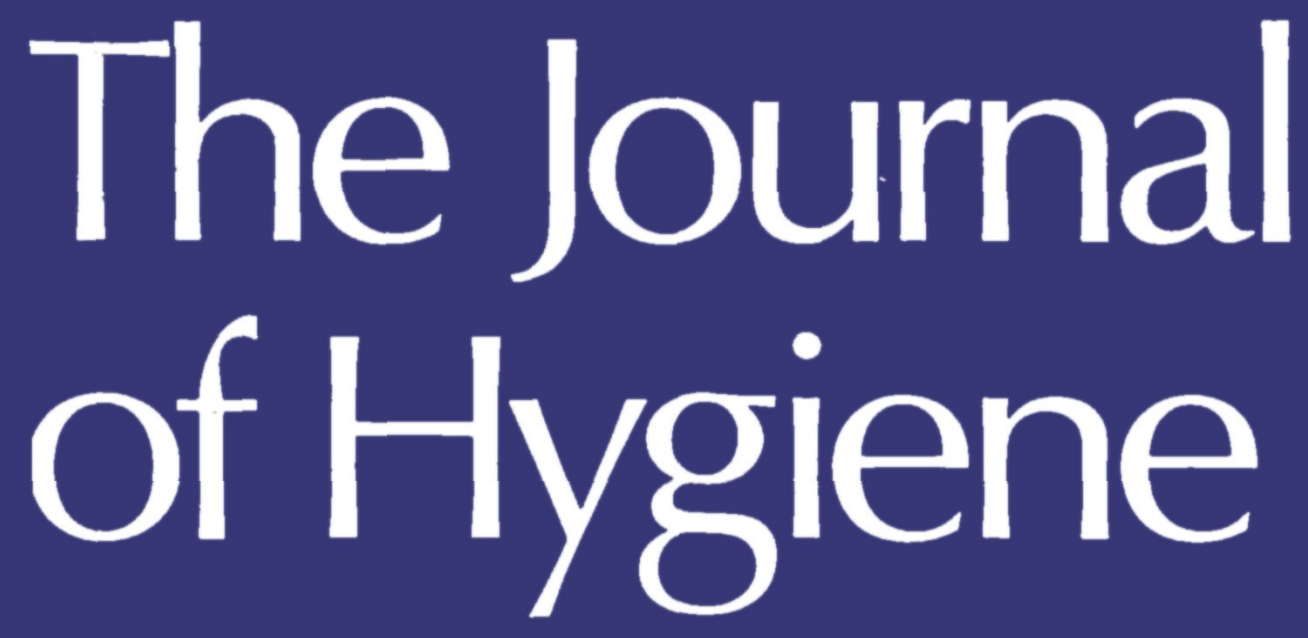

Original reports and reviews

on all aspects of infection

of man and animals.

Volume 97 Number 2 October 1986

Cambridge University Press 


\title{
The Journal of Hygiene
}

\author{
EDITED BY \\ J. R. Pattison \\ Professor of Medical Microbiology \\ University College, London and the Middlesex Hospital Medical School \\ C. R. Madeley \\ Professor of Virology, \\ University of Newcastle \\ upon Tyne \\ Assistant editor \\ P. Morgan-Capner \\ Consultant Virologist, \\ Public Health Laboratory, \\ Preston \\ W. C. Noble \\ Professor of Microbiology, \\ Institute of Dermatology, \\ London
}

\begin{abstract}
J. G. Cruikshank
Consultant Microbiologist,

Public Health Laboratory, Exeter, Devon
\end{abstract}

\section{IN CONJUNCTION WITH}
M. J. Anderson (London)
R. M. Anderson (London)
R. D. Barry (Australia)
P. S. Brachman (Atlanta)
M. Degré (Oslo)
S. M. Feinstone (Bethesda)
R. G. Finch (Nottingham)
R. J. Gilbert (London)
Anna Hambraeus (Uppsala)
M. H. Hinton (Bristol)
J. B. Kurtz (Oxford)
J. C. de Jong (Bilthhoven)
M. J. Lewis (Nottingham)
D. H. Lloyd (London)
R. R. Marples (London)
O. H. Meurman (Turku)
P. P. Mortimer (London)
J. S. Oxford (London)
R. F. Sellers (Pirbright)
M. B. Skirrow (Worcester)

R. S. Tedder
(London)
H. E. Tillett
(London)
D. van der Warij
(Groningen)
H. Williams-Smith
(Huntingdon)
A. T. Willis (Luton)
Sir Graham Wilson

(London)

The Journal of Hygiene publishes reports of research and original findings in subjects related to infectious diseases. Particular emphasis is given to the epidemiology, prevention and control of such diseases, but the field covered is broad and includes the microbiological, virological, immunological, clinical and social aspects of infectious diseases of man and animals.

(C) Cambridge University Press 1986

\section{Copying}

\section{PERMISSIONS}

This journal is registered with the Copyright Clearance Center, 21 Congress Street, Salem, Mass, 01970. Organizations in the USA who are also registered with the C.C.C. may therefore copy material (beyond the limits permitted by sections 107 and 108 of US copyright law) subject to payment to C.C.C. of the per-copy fee of \$05.00. This consent does not extend to multiple copying for promotional or commercial purposes. Code 0022-1724/86/2828-0001 \$05.00.

ISI Tear Service, 3501 Market Street, Philadelphia, Pennsylvania 19104, USA, is authorized to supply single copies of separate articles for private use only.

For all other use, permission should be sought from Cambridge or the American Branch of Cambridge University Press.

\section{SUBSCRIPTIONS}

The Journal of Hygiene (ISSN 0022-1724) is published annually in two volumes of three parts in February, April, June, August, October and December.

The subscription price of volumes 96 and 97, 1986, is $\$ 42$ net (USA and Canada. US 999.50) per volume (post free); single parts are available at 117 net (USA and Canada US 842) plus postage. Back volumes are also available. Orders, which must be accompanied by payment, may be sent to any bookseller or subscription agent or to the publisher: Cambridge Unniversity Press, The Edinburgh Building, Shaftesbury Road, Cambridge CB2 2RU, or in the USA and Canada to Cambridge University Press, 32 East 57th Street, New York, NY 10022. Second class postage paid at New York, NY, and at additional mailing offices. POSTMASTER : send address changes in USA and Canada to the Journal of Hygiene, Cambridge University Press, 32 East 57th Street, New York, NY 10022.

Claims for missing issues should be made immediately on receipt of the subsequent issue. 